\title{
Thickness of the lithosphere beneath Turkey and surroundings from S-receiver functions
}

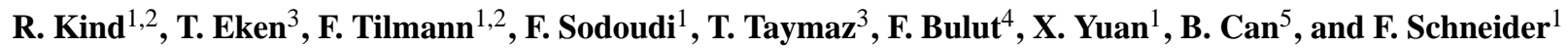 \\ ${ }^{1}$ Deutsches GeoForschungsZentrum GFZ, Potsdam, Germany \\ ${ }^{2}$ Freie Universität, Fachrichtung Geophysik, Berlin, Germany \\ ${ }^{3}$ Department of Geophysical Engineering, The Faculty of Mines, Istanbul Technical University, 34469 Maslak, \\ Istanbul, Turkey \\ ${ }^{4}$ Istanbul Aydin University, AFAM D. A. E. Research Centre, Istanbul, Turkey \\ ${ }^{5}$ Bogaziçi University, Kandilli Observatory and Earthquake Research Institute (KOERI), Istanbul, Turkey
}

Correspondence to: R. Kind (kind@gfz-potsdam.de)

Received: 9 March 2015 - Published in Solid Earth Discuss.: 10 April 2015

Revised: 8 July 2015 - Accepted: 15 July 2015 - Published: 31 July 2015

\begin{abstract}
We analyze S-receiver functions to investigate variations of lithospheric thickness below the entire region of Turkey and surrounding areas. The teleseismic data used here have been compiled combining all permanent seismic stations which are open to public access. We obtained almost 12000 S-receiver function traces characterizing the seismic discontinuities between the Moho and the discontinuity at $410 \mathrm{~km}$ depth. Common-conversion-point stacks yield wellconstrained images of the Moho and of the lithosphereasthenosphere boundary (LAB). Results from previous studies suggesting shallow LAB depths between 80 and $100 \mathrm{~km}$ are confirmed in the entire region outside the subduction zones. We did not observe changes in LAB depths across the North and East Anatolian faults. To the east of Cyprus, we see indications of the Arabian LAB. The African plate is observed down to about $150 \mathrm{~km}$ depth subducting to the north and east between the Aegean and Cyprus with a tear at Cyprus. We also observed the discontinuity at $410 \mathrm{~km}$ depth and a negative discontinuity above the 410 , which might indicate a zone of partial melt above this discontinuity.
\end{abstract}

\section{Introduction}

The lower boundary of the lithospheric plate is a very important parameter for understanding plate tectonics, although it is still one of the less known quantities. Our current knowledge of the lithospheric thickness beneath Turkey re- lies on studies that examined the data from several temporary and permanent seismic networks (e.g., Angus et al., 2006; Sodoudi et al., 2006, 2015; Gök et al., 2007, 2015; Vanacore et al., 2013; Vinnik et al., 2014). Interpretations from these studies are either confined to a limited region or to a limited depth extent, i.e., to crustal depths only. Thus, the variations of lithospheric thickness have not yet been homogeneously characterized in Turkey and surroundings. A robust estimate of the lithospheric thickness is an important constraint for our understanding of mantle deformation in response to tectonic forces (see Fischer et al., 2010, and Jones et al., 2010, for reviews). In the present study, we provide a complete image of the LAB topography below Anatolia and adjacent regions based on a combination of data from several different networks in the area. To achieve this, we have employed the S-receiver function technique, which is particularly suited to identify seismic discontinuities in the upper mantle, especially when low-velocity zones are involved.

\section{Tectonic setting}

The Cenozoic closure of the Tethys Ocean and the following continental collision of the northward-moving African and Arabian plates with the Eurasian plate are considered to be the main driving processes of the present tectonic setting in the eastern Mediterranean and Anatolia (Şengör and Kidd, 1979; Dewey and Şengör, 1979; Taymaz et al., 1990, 1991a,b; Jackson et al., 1992; Armijo et al., 1999; Taymaz 


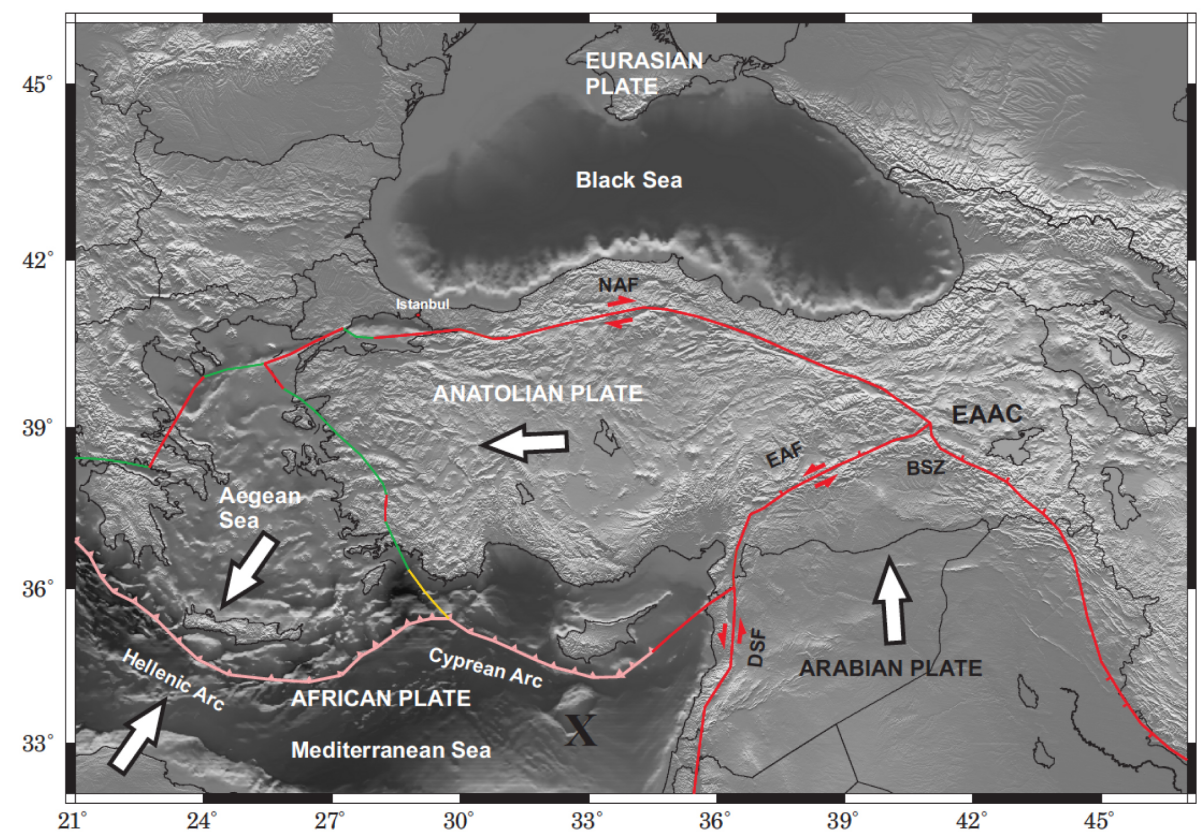

Figure 1. Tectonic map of the study area. The major plate boundary data are taken from Bird (2003). Subduction zones are pink, continental transform faults are red, continental rift boundaries are green, and spreading ridges boundaries are yellow. EAAC, NAF, EAF, and DSF are the East Anatolian Accretionary Complex, North Anatolian Fault, East Anatolian Fault, and the Dead Sea fault, respectively. X marks the Eratosthenes Seamount.

et al., 2004; Faccenna et al., 2014; Schildgen et al.; 2014). Figure 1 summarizes the tectonic setting of the target area. GPS measurements have highlighted that the retreating Hellenic trench and associated slab roll-back of the subducting African lithosphere are currently the major driving forces for the western movement of the Anatolian plate (e.g., McKenzie, 1978; Reilinger et al., 2006). Current deformation is mainly accommodated through strain localization along the North Anatolian Fault (NAF) and the East Anatolian Fault (EAF). The deformation along the EAF is purely left lateral with no compressional component except for localized thrust ridges associated with strike-slip tectonics (Bulut et al., 2012). Body wave tomography images on global and regional scale indicate that the Hellenic subduction penetrates down to the lower mantle with an average dip of about $40^{\circ}$ (Wortel and Spakman, 2000; Faccenna et al., 2006; Biryol et al., 2011; Salaün et al., 2012) while a recent waveform tomography study by Fichtner et al. (2013a, b) did not report any deep slab.

Crustal thickness ranges from 35 to $40 \mathrm{~km}$ along the North Anatolian Fault and shallows to $25-30 \mathrm{~km}$ in the Sea of Marmara region based on receiver functions and controlled source studies (Saunders et al., 1998; Sato et al., 2004; Zor et al., 2006; Laigle et al., 2008; Özacar et al., 2008; Bécel et al., 2009, 2010; Vanacore et al., 2013; Karabulut et al., 2013; Sodoudi et al., 2015). The lithosphere-asthenosphere boundary beneath the East Anatolian Accretionary Complex (EAAC) has been observed at $60-80 \mathrm{~km}$ depth based on S- receiver functions (Angus et al., 2006). They consider this lithospheric thickness to be anomalously thin and interpret this structure to be the remnant of the detachment of an oceanic slab. Further evidence for a thin lithosphere overlying hot and partially molten asthenospheric material beneath eastern Anatolia has been found in other P- and S-receiver function images (Zor et al., 2003; Özacar et al., 2008; Vanacore et al., 2013). Other indications of a shallow LAB are strong attenuation of Lg and Sn phases (Gök et al., 2003) and relatively low Pn- and uppermost mantle S-velocities (Al-Lazki et al., 2004, Maggi and Priestley, 2005). The slow velocity anomaly was attributed to the ascending asthenosphere that is emplaced beneath the plateau following the detachment of the northward-subducting Arabian oceanic lithosphere (Keskin, 2003; Faccenna, 2003; Şengör et al., 2003; Biryol et al., 2011; Fichtner et al., 2013a, b). Recently, tomography studies by Biryol et al. (2011) and Fichtner et al. (2013a) have confirmed that a hot and buoyant asthenospheric body supports the $\sim 2 \mathrm{~km}$ elevation of the Eastern Anatolian Plateau in the presence of an about $45 \mathrm{~km}$ thick crust (Şengör et al., 2003; Zor et al., 2003). At about $350 \mathrm{~km}$ depth, a fast anomaly has been found by tomographic studies and interpreted to represent a slab detachment (Lei and Zhao, 2007; Zor, 2008). 


\section{Data and method}

Recent extensions of seismic and geodetic networks in Turkey have considerably contributed to our understanding of seismicity patterns and crustal and lithospheric structures beneath Anatolia and the surrounding regions. These developments have been triggered in particular by the destructive 1999 Izmit $\left(M_{w} 7.4\right)$ and Düzce $\left(M_{w} 7.2\right)$ earthquakes. Our data set consists of teleseismic waveforms that were extracted from 1028 earthquakes recorded at 195 broadband stations (Fig. 2), operated by Kandilli Observatory and Earthquake Research Institute (KOERI; Kalafat et al., 2008), NOA-Net, Aristotle University Thessaloniki (HT-Net) and GEOFON (Hanka and Kind, 1994; GEOFON Data Centre, 1993).

We apply the S-receiver function method to this data set in order to image seismic discontinuities in the crust and upper mantle. A description of the S-receiver function analysis scheme and examples are found in Yuan et al. (2006) and Kind et al. (2012, 2014). The method employs teleseismic $\mathrm{S}$ phases, which are converted to $\mathrm{P}$ waves at a discontinuity below the station site. The main advantage of this approach over the P-receiver function technique is that there is practically no interference from multiples, which can otherwise significantly interfere with the imaging of deeper convertors, in particular for the depth range of $80-200 \mathrm{~km}$ in continental regions. S-receiver functions provide a broad sampling of the upper mantle comparable to the steep angle reflection images of the crust. This technique requires a sufficient number of high-quality observations of teleseismic $S$ phases, typically at least about 60 records per station with signal-to-noise ratio above two. Permanent broadband stations or densely deployed temporary broadband networks can usually provide this amount of data. The limit of resolution is determined by the frequency content of teleseismic $\mathrm{S}$ phases, which usually only give convincing results for periods longer than a few seconds. Since the essential part of Sreceiver functions consists of weakly converted P-precursors of the SV phase, the signal-to-noise ratio needs to be improved by stacking large number of records at the same station, or within a confined region of conversion points at a fixed depth, or by migrating the rays into the depth domain based on a 1-D reference model and the assumption that conversions occur at horizontal boundaries. The latter approach is known as a common-conversion-point stack (CCP). To reduce source side effects, the distribution of sources should have a well-balanced azimuthal and epicentral coverage. In general, events at epicentral distances between $60^{\circ}$ and $85^{\circ}$ are suitable for S-receiver function studies. Reviews of the application of the S-receiver function technique in investigations of the lithosphere-asthenosphere boundary are found in Rychert and Shearer (2009), Fischer et al. (2010) and Rychert et al. (2010). More recently, further studies of uppermantle discontinuities have been published by Levander and
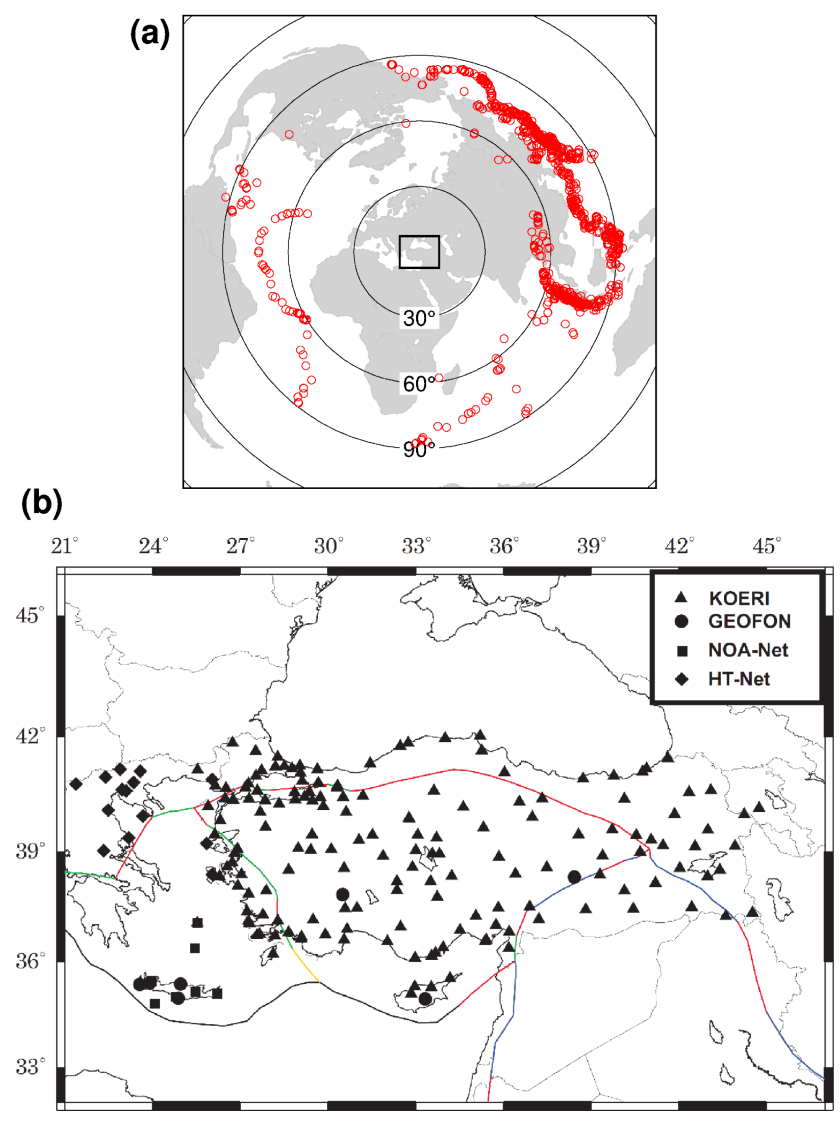

Figure 2. (a) Epicentral distribution of 1028 teleseismic events $\left(\mathrm{M}_{\mathrm{W}}>5.5\right)$ with epicentral distances ranging from 60 to $85^{\circ}$, marked with red circles. (b) Distribution of 195 analyzed broadband stations of the KOERI (triangles), GEOFON (circles), NOANet (squares) and HT-Net (diamonds) networks.

Miller (2012), Kumar et al. (2012a, b), Hopper et al. (2013), Kind et al. (2013) and Sodoudi et al. (2013).

We have restricted the data set by visual inspection to reasonably simple and clear waveforms. Deconvolution results that fail to transform the SV signal (Q component) into a sharp spike have also been excluded based on a further visual inspection. This resulted in 11660 S-receiver functions. For initial evaluation, all traces are combined within nonoverlapping $0.5^{\circ}$ epicentral distance bins irrespective of the station and source locations (Fig. 3). This figure shows all observable precursors of the $\mathrm{S}$ phases, including phases that might disturb the expected S-to-P conversion from uppermantle discontinuities below the stations. A positive conversion (red) at $-3 \mathrm{~s}$, corresponding to the Moho, and a negative (blue) signal at $-10 \mathrm{~s}$, interpreted as the LAB, are clearly visible. We can also identify the SKS660p and ScS660p phases caused by S-to-P conversions of SKS and ScS at the $660 \mathrm{~km}$ discontinuity. These signals have significantly different slowness compared to the $\mathrm{S}$-to- $\mathrm{P}$ conversions of the $\mathrm{S}$ phase at the LAB or Moho, meaning that they cut across all other phases before the $\mathrm{S}$ signal. It means that, if we apply proper delays 


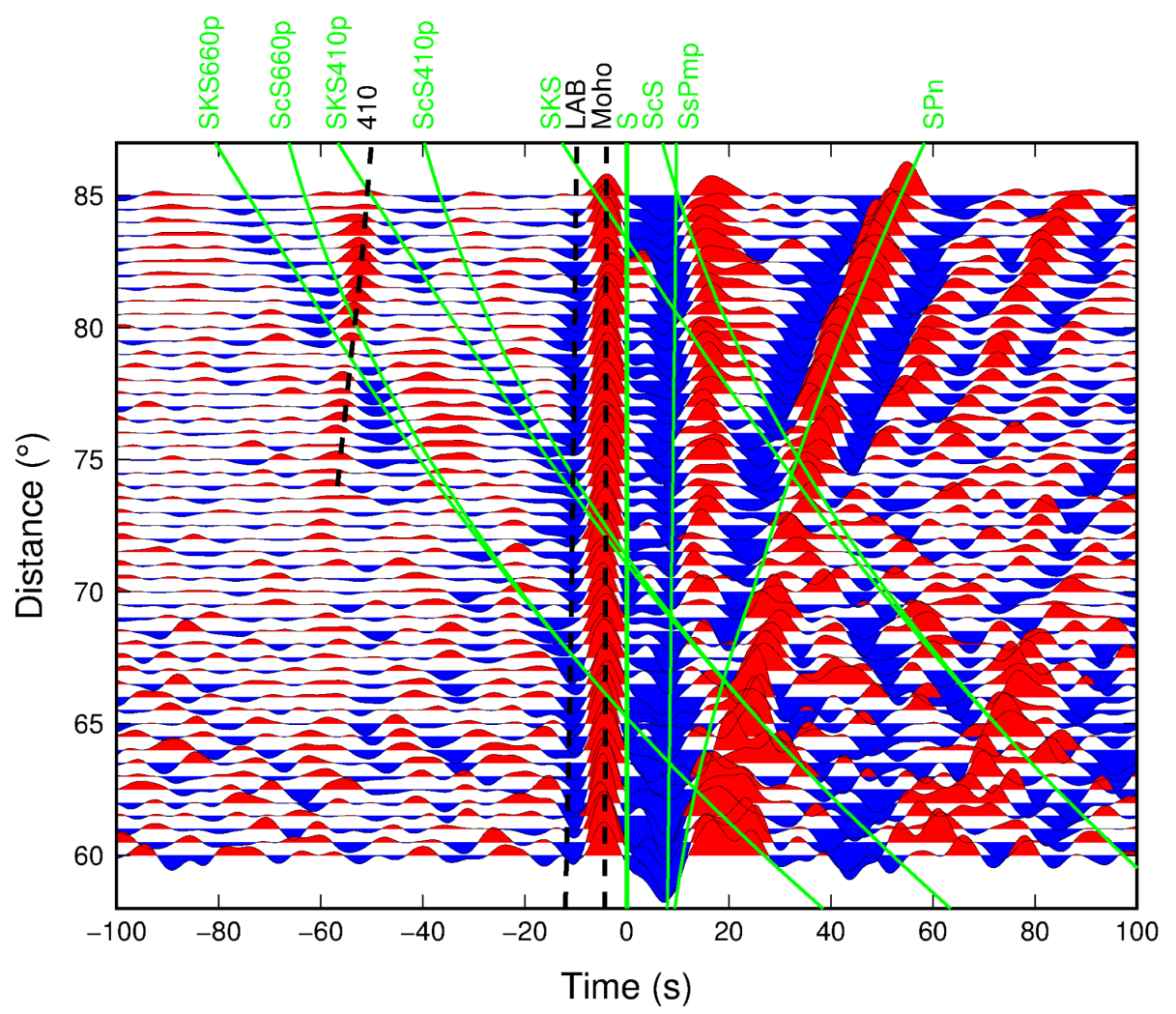

Figure 3. Stacks of all 11660 S-receiver functions as a function of the epicentral distance (binned in $0.5^{\circ}$ distance windows). The traces are lined up along the theoretical arrival time of the SV phase. Data are deconvolved and filtered with a $8 \mathrm{~s}$ low-pass filter. Theoretical arrival times of several phases are marked.

before summation according to the slowness of the converted $\mathrm{S}$ phase, all other phases traveling with different slowness are suppressed. The strong signal following $\mathrm{S}$ is the SPn phase, which is caused by an S-to-P conversion traveling horizontally as a $\mathrm{P}$ wave through the uppermost mantle layer at the receiver side.

\section{Synthetic tests for imaging inclined structures with $\mathrm{S}$-receiver functions}

Since we expect to image in the south of the study region an inclined slab, we first use synthetic seismograms to quantify the magnitude of artifacts which may occur during the depth transformation of the time domain records and infer the maximum range of inclination at which the LAB of a slab can be imaged using S-receiver functions. Figure $4 a-f$ show synthetic seismograms calculated with the RAYSUM software (Frederiksen and Bostock, 2000), which is capable of calculating receiver functions for inclined layers. In these figures, the converters used for the forward modeling are displayed by black lines. Positive and negative amplitudes of the synthetic S-RFs (S-receiver functions) are shown by red and blue, respectively. Based on available reference tomographic models (e.g., Biryol et al., 2011; Bakirci et al., 2012), an inclined $45 \mathrm{~km}$ thick high-velocity zone (slab) dipping to the north is used as the input model. The modeling has been performed for inclination angles between $0^{\circ}$ and $50^{\circ}$ with an increment of $10^{\circ}$. The velocity contrasts are from 8.0 to $7.5 \mathrm{~km} \mathrm{~s}^{-1}$ at the lower boundary of the slab and from 6.5 to $8.0 \mathrm{~km} \mathrm{~s}^{-1}$ at its upper boundary, as depicted in Fig. 4a. S$\mathrm{RF}$ traces are modeled for back azimuths from $0^{\circ}$ to $180^{\circ}$ with an increment of $10^{\circ}$ and for a constant slowness of $9.8 \mathrm{~s} \mathrm{degree}^{-1}$, which corresponds to an epicentral distance of $80^{\circ}$. Events with back azimuths from $180^{\circ}$ to $360^{\circ}$ would yield identical information to that obtained for the range 0 $180^{\circ}$ due to the $180^{\circ}$ periodicity of RFs for inclined structures. Figure $4 \mathrm{~g}$ shows the incidence angle of the incoming $\mathrm{S}$ wave at the lower boundary of the dipping slab as a function of the back azimuth. For zero and small incidence angles of the high-velocity zone, the discontinuities are properly imaged at expected positions (see Fig. 4a, b). A signal is generated by events from nearly all azimuths. For a slab inclination greater than $20^{\circ}$, the lower boundary of the slab is imaged only by events from southern directions since for back azimuths of $90^{\circ}$ the emergent angle of the converted $\mathrm{Sp}$ wave reaches its critical value (see green line in Fig. $4 \mathrm{~g}$ ). Thus, for events from northern azimuths $\left(0-90^{\circ}\right)$, no transmitted Sp conversion exists. For larger inclinations of the 

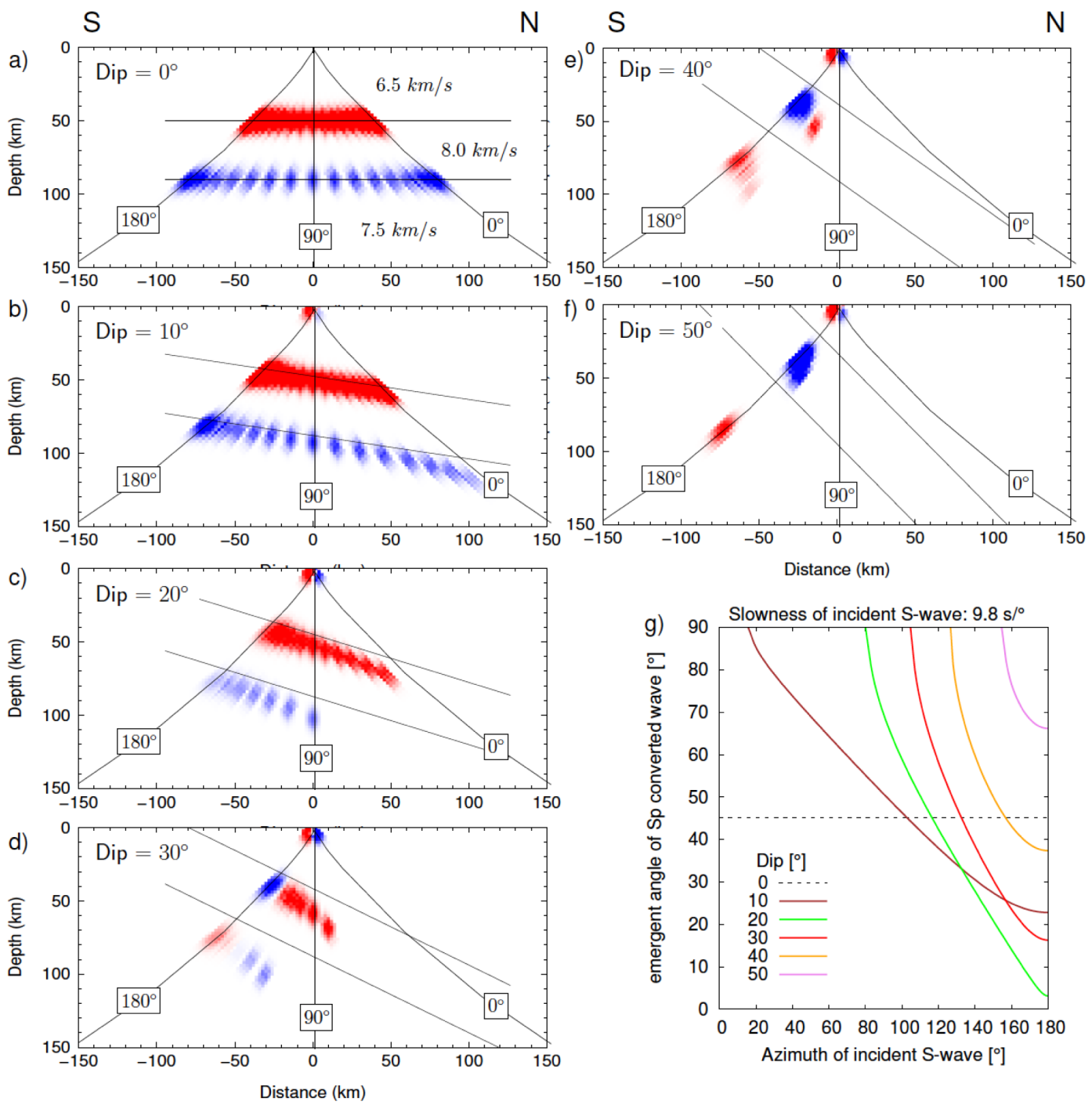

Figure 4. Common conversion point (CCP) stacking results of synthetic S-receiver functions generated with the RAYSUM package (Frederiksen and Bostock, 2000) for different inclination angles of a high-velocity zone (slab). The converters of the input models are depicted as black lines. The velocities used for the modeling are given in (a). The locations of the converters as reconstructed by CCP stacking of the synthetic S-receiver function amplitudes are shown in red (positive) and blue (negative). As for the depth transformations, a 1-D velocity model is used for calculating the conversion points, resulting in the offset between input and recovered anomalies for inclined discontinuities. (g) The emergent angles (relative to the slab surface) of the Sp converted and transmitted waves are calculated dependent on the back azimuth of the incident $S$ wave for the velocity contrast at the lower boundary of the slab. The results for the different considered inclination angles (dip) are shown in different colors. The range of back azimuths for which Sp converted energy is transmitted is becoming smaller for increasing dipping angle.

slab, the back azimuthal range for which Sp converted energy is transmitted becomes even smaller (see Fig. $4 \mathrm{~d}-\mathrm{f}$ and red, yellow and violet lines in Fig. 4g). Moreover, the amplitudes from the inclined structure show a reversal for slab inclinations larger than $30^{\circ}$ and events from southern directions $\left(160-180^{\circ}\right)$. This amplitude reversal occurs similarly for the Q-component of P-RFs from inclined structures (Schneider et al., 2013) and might cause destructive interference in CCP stacks.

\section{Observations and interpretation}

We extracted several north-south and east-west profiles through Anatolia. The results from time domain stacks and depth transformations are shown in Figs. 5-10. The receiver functions are filtered with an $8 \mathrm{~s}$ low-pass filter in those figures. In the time domain, a moveout correction is applied using a reference slowness of $6.4 \mathrm{~s} \mathrm{degree}^{-1}$ and time-corrected traces are stacked for S-to-P piercing points at $200 \mathrm{~km}$ depth within a certain window of latitude and longitude along 
(a)
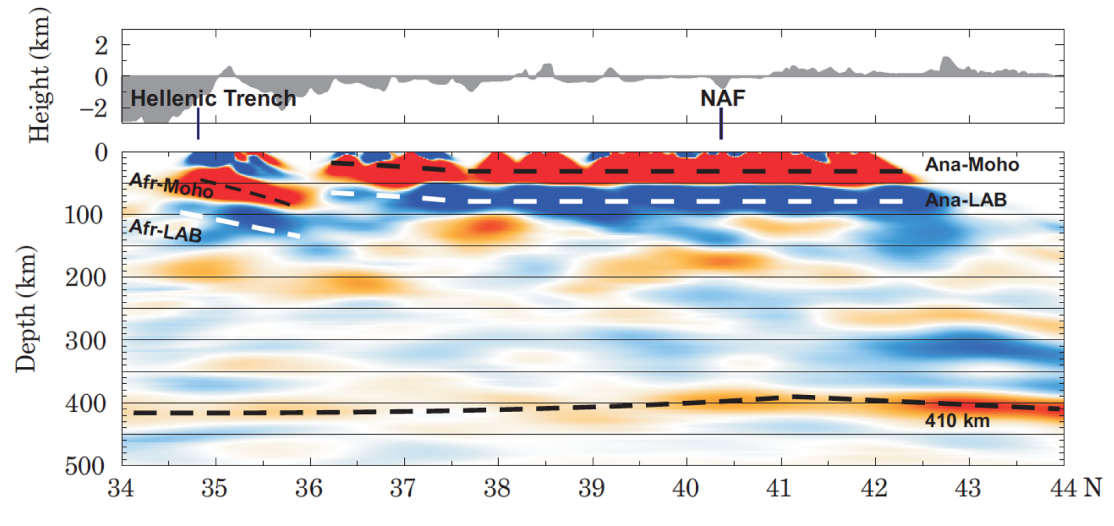

(b)
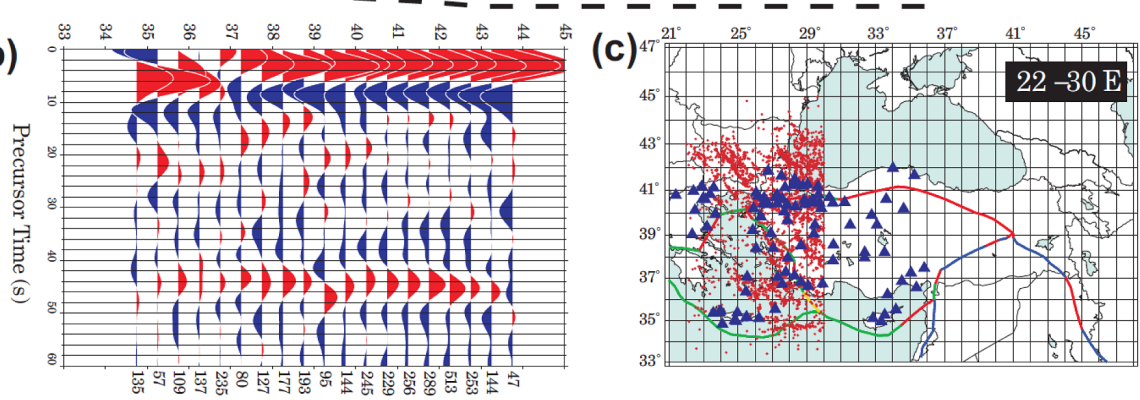

Figure 5. Display of S-receiver functions along a north-south profile between 22 and $30^{\circ} \mathrm{E}$ (Aegean and western Anatolia). Topography is displayed on top of the figure. (a) CCP stack (depth-transformation). (b) Time-domain stack for same profile as in (a). A slowness of $6.4 \mathrm{~s} \mathrm{degree}^{-1}$ is used for the moveout correction. The binning is determined by the location of piercing points at $200 \mathrm{~km}$ depth. The numbers below the bottom $y$ axis show how many traces have contributed to each trace. (c) Blue triangles are stations which contributed data to the profile. Red dots are locations of S-to-P piercing points at $200 \mathrm{~km}$ depth.

the selected profiles. We chose the piercing point depth of $200 \mathrm{~km}$ in the time domain images in order to focus on potentially subducting structures. The summation windows have been placed along east-west and north-south profiles. The size of the windows is $0.3^{\circ}$ in the north-south (or eastwest) direction and the width of the section in the east-west (or north-south) direction given in each figure caption (e.g., Fig. 5). Neighboring boxes are not overlapping: no lateral smoothing is applied along the profiles. The relatively large profile widths $\left(3-9^{\circ}\right)$ were required to collect a sufficient number of traces to ensure a good signal-to-noise ratio of the originally weakly converted phases in the summation trace. In order to obtain an image directly in the depth-distance domain, we also calculated CCP stacks, which, unlike the time domain summation, does not require the arbitrary choice of a piercing point depth. We assumed the IASP91 global reference model for the time-to-depth conversion. The receiver function depth transformation technique does not depend strongly on the given velocity model. The same profile width as in the time domain technique is used in the depth transformation technique, and all rays traveling within the profile width at any depth are summed. This means that, generally, more traces contribute to each profile in the depth domain because for the time-domain images only rays with piercing points in a particular depth are summed.

\subsection{Moho}

A positive converter associated with the Moho is very obvious in all profiles in Figs. 5-10.

The Moho is only briefly discussed here as it is not the main target of this study. Basically, shorter-period P-receiver functions are more suitable for a detailed image of the Moho or intracrustal discontinuities. However, we point out a few crustal observations obtained from S-receiver functions. The crustal thickness increases from the Aegean to eastern Anatolia from $\sim 25$ to $\sim 40 \mathrm{~km}$ (see Fig. 9). As the seismic traces are averaged with piercing points in relatively large grids $\left(1^{\circ}\right.$ longitude, $4^{\circ}$ latitude in Fig. 9$)$, small-scale variations of the Moho are not well-resolved. The observed range of the Moho depths is consistent with results from previous receiver function studies (e.g., Saunders et al., 1998; Zor et al., 2006; Özacar et al., 2008; Vanacore et al., 2013; Karabulut et al., 2013). However, in eastern Anatolia, Şengör et al. (2003) and Zor et al. (2003) reported that the Moho depth increases from less than $40 \mathrm{~km}$ at the Bitlis suture to about $50 \mathrm{~km}$ near the Black Sea. This deep Moho is not seen in our data (Fig. 7), implying that this change in Moho depth only occurs in a limited region, such that it is not visible in our relatively large-scale north-south profile in Fig. 7. Vanacore et al. (2013) presented a detailed Moho map from P-receiver 
(a)
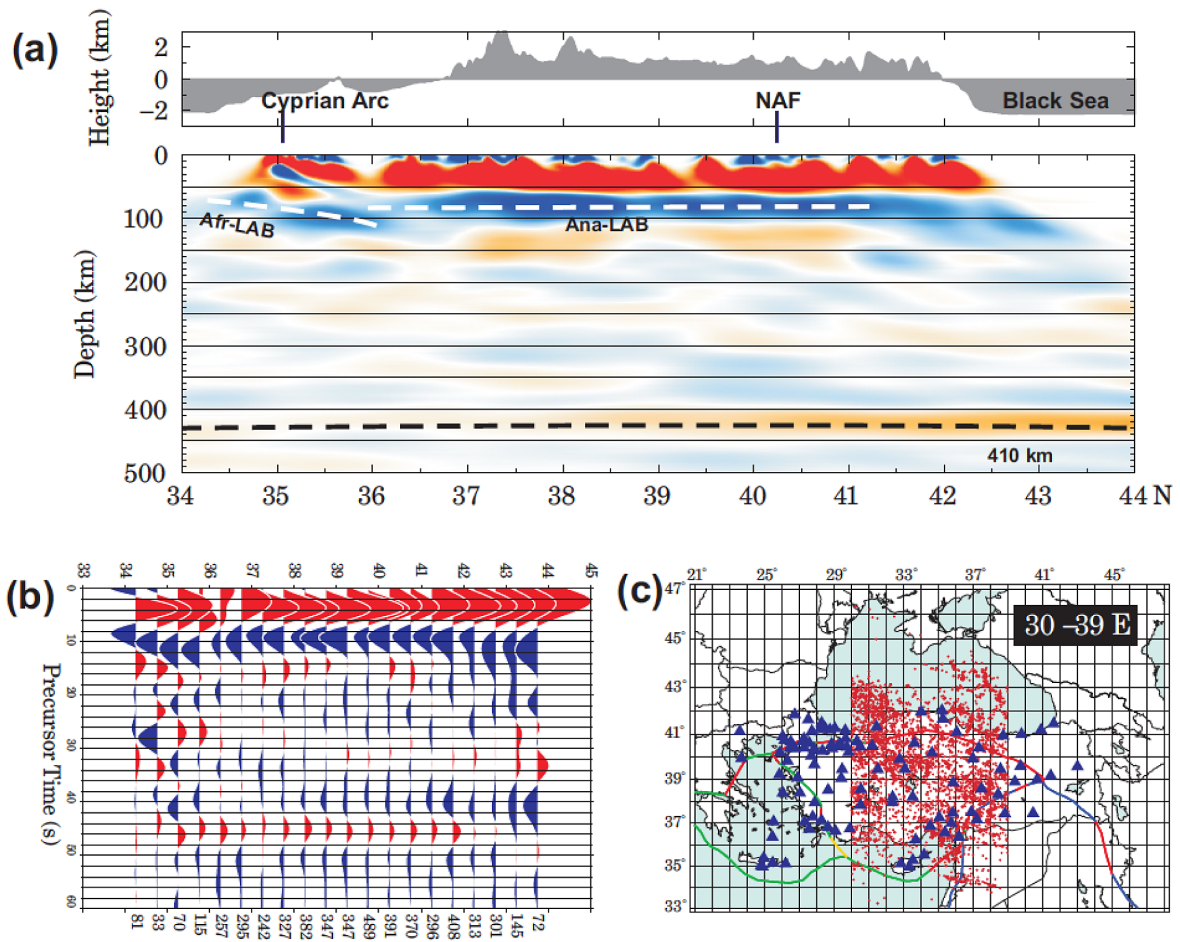

Figure 6. Same as Fig. 5 for a north-south profile between 30 and $39^{\circ} \mathrm{E}$ (central Anatolia). The width of this profile is too wide to see details of the subduction near Cyprus. See Fig. 8 for more details. No change in depth across the North Anatolian Fault is noticeable (NAF in a).

(a)

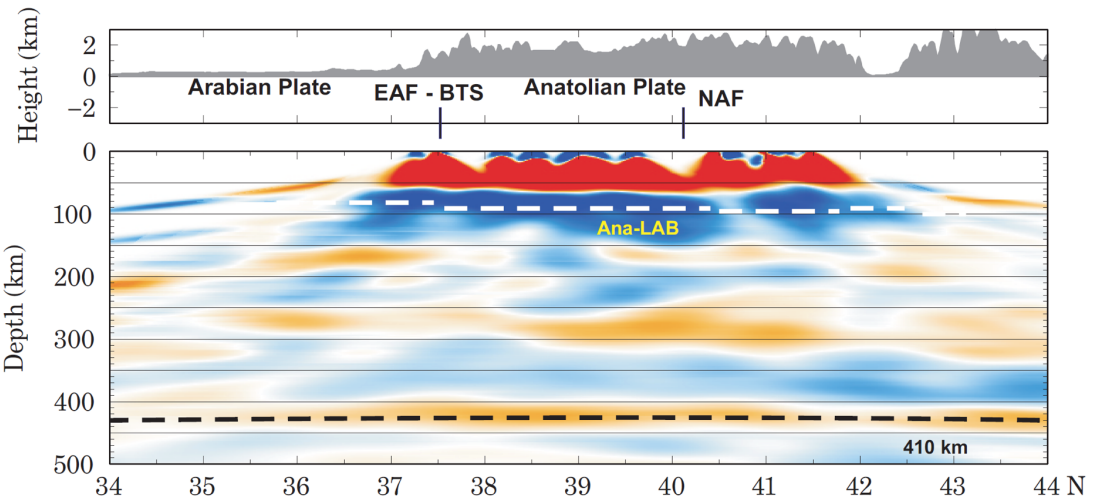

(b)

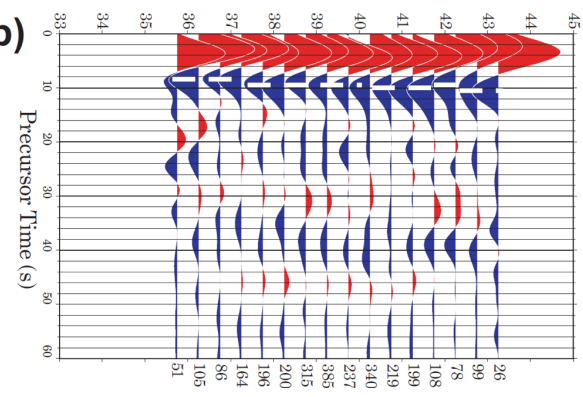

(c)

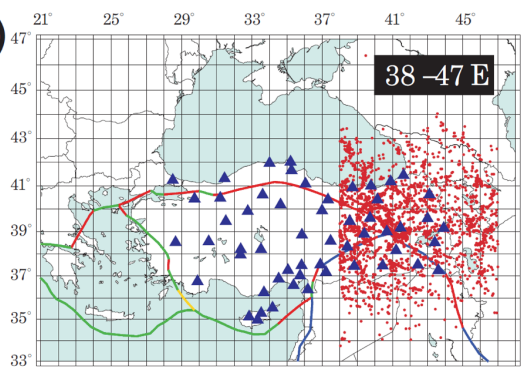

Figure 7. Same as Fig. 5 for a north-south profile between 38 and $47^{\circ} \mathrm{E}$ (eastern Anatolia). A flat Anatolian LAB is visible; no subducting LAB can be seen. 
(a)

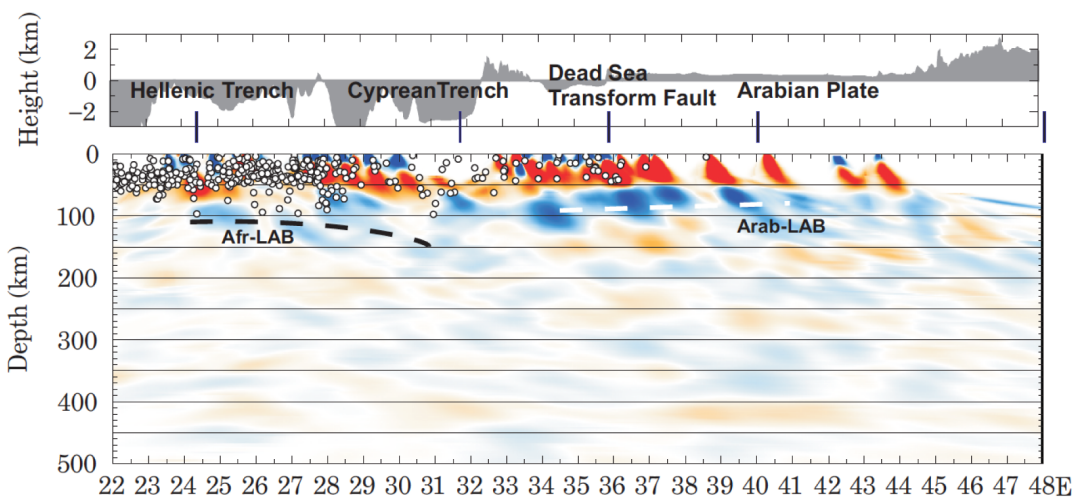

(b)
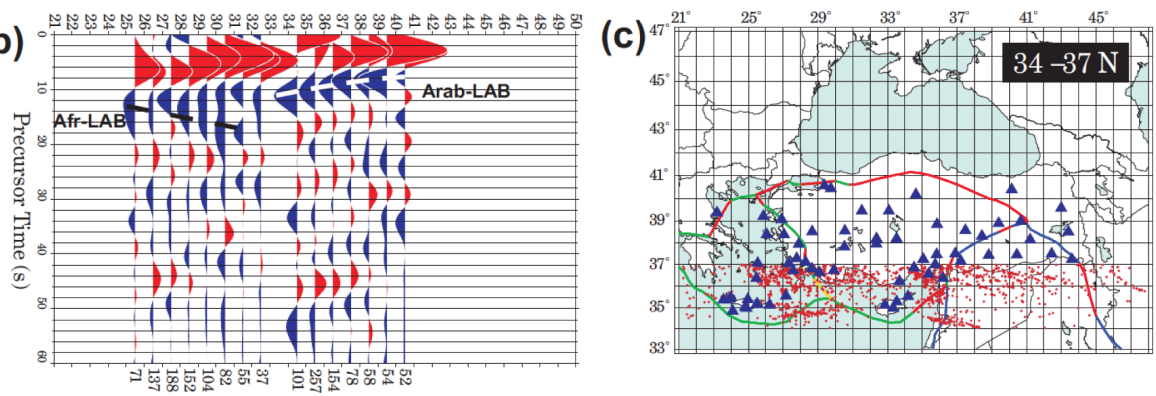

Figure 8. Same as Fig. 5 for an east-west profile between 34 and $37^{\circ} \mathrm{N}$ along southern Anatolia. The African LAB appears to deepening from near $100 \mathrm{~km}$ depth below the Aegean and western Anatolia to about $200 \mathrm{~km}$ depth at the western edge of Cyprus. Further to the east the $\mathrm{LAB}$ is strong and shallow. White circles projected on the migrated depth section of (a) represent the hypocenters of earthquakes between 1998 and 2014 (catalogue of International Seismological Center).

functions. They also observed a general increase in Moho depth from west to east, which is roughly consistent with our S-RF results. The subducting African Moho is visible to a depth of nearly $100 \mathrm{~km}$ in the southern part of western Anatolia and the Aegean (Fig. 5a). No significant change in Moho depth is visible across the North Anatolian Fault in the south-north profiles (see, e.g., Fig. 6). However, our data are filtered with an $8 \mathrm{~s}$ low-pass filter and therefore not optimized for higher-resolution determination of the Moho depth across the NAF. P-receiver functions are more useful for this purpose.

\subsection{Lithosphere-asthenosphere boundary}

The stacked S-RF images in Figs. 5-10 show a clear observation of a relatively homogeneous negative discontinuity at $80-100 \mathrm{~km}$ depth beneath the entire region, which we interpret to represent the LAB. This signal is not a side lobe of the Moho for the following reason. Seismic signals are causal: there is no signal in the unfiltered records before the arrival time. We found LAB signals in unfiltered and undeconvolved traces in the same depth range as in filtered and deconvolved traces (see Fig. 11a), which proves that they correspond to a physical discontinuity The smooth appearance of the LAB in Figs. 5-10 is due to the chosen filter ( $8 \mathrm{~s}$ low-pass). Using shorter wavelengths or no filter, the LAB dissolves into several discontinuous signals (see Fig. 11a). More such examples in North America are shown in the final version of Kind et al. (2015). Such a laminated structure of the mantle lithosphere in western Europe has been known for a long time from long-range controlled source experiments (e.g., Kind, 1974). The new receiver function data seem to confirm the laminated structure. We conclude that the bottom of the lithosphere consists of several neighboring laterally and vertically limited discontinuities with decreasing velocity downward. The vertical extent of the laminated region is up to $50 \mathrm{~km}$ (Fig. 11a). Due to the superposition of neighboring signals, the depth and amplitudes of the longer-period filtered LAB depend on the period. We have chosen this relatively long-period filter to emphasize the dominant structures in the mantle as clearly as possible. The Moho and the 410 and 660 discontinuities have different characteristics and become sharper when shorter periods are used, indicating that they are simple first-order discontinuities.

Our observations of a shallow LAB beneath Anatolia confirm earlier results. Previous findings mainly from body and surface wave tomography studies (Biryol et al., 2011; Bakirci et al., 2012; Salaün et al., 2012; Fichtner et al., 2013a, b) indicate a similarly thin lithosphere beneath entire Anatolia. Additional constraints confirming a thin lithosphere are provided by the much smaller-scale P-RF and S-RF images in Sodoudi et al. (2006, 2015), Angus et al. (2006), Özacar et 
(a)

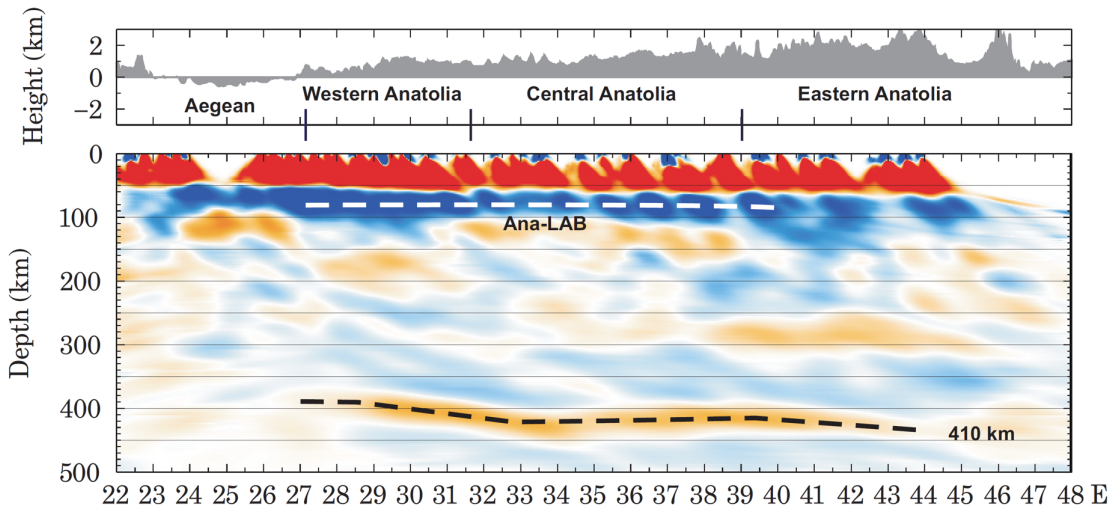

(b)

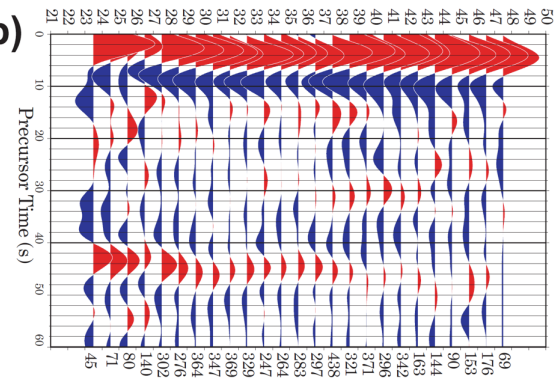

(c)

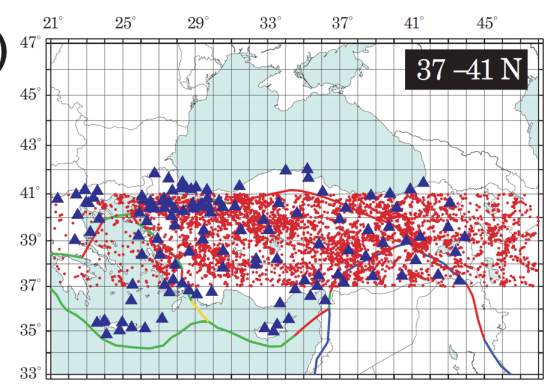

Figure 9. Same as Fig. 5 for an east-west profile between 37 and $41^{\circ} \mathrm{N}$ along central Anatolia. LAB (white dashed line) and Moho (black dashed line) are marked in (a) and (b). Both phases are strong signals and slightly dipping from west to east. The Moho is on average in the west at about $25 \mathrm{~km}$ depth and in the east at about $40 \mathrm{~km}$ depth. The LAB depth deepens from about $80 \mathrm{~km}$ in the west to about $90 \mathrm{~km}$ in the east. Below the Aegean we see indications of the subducting African LAB.
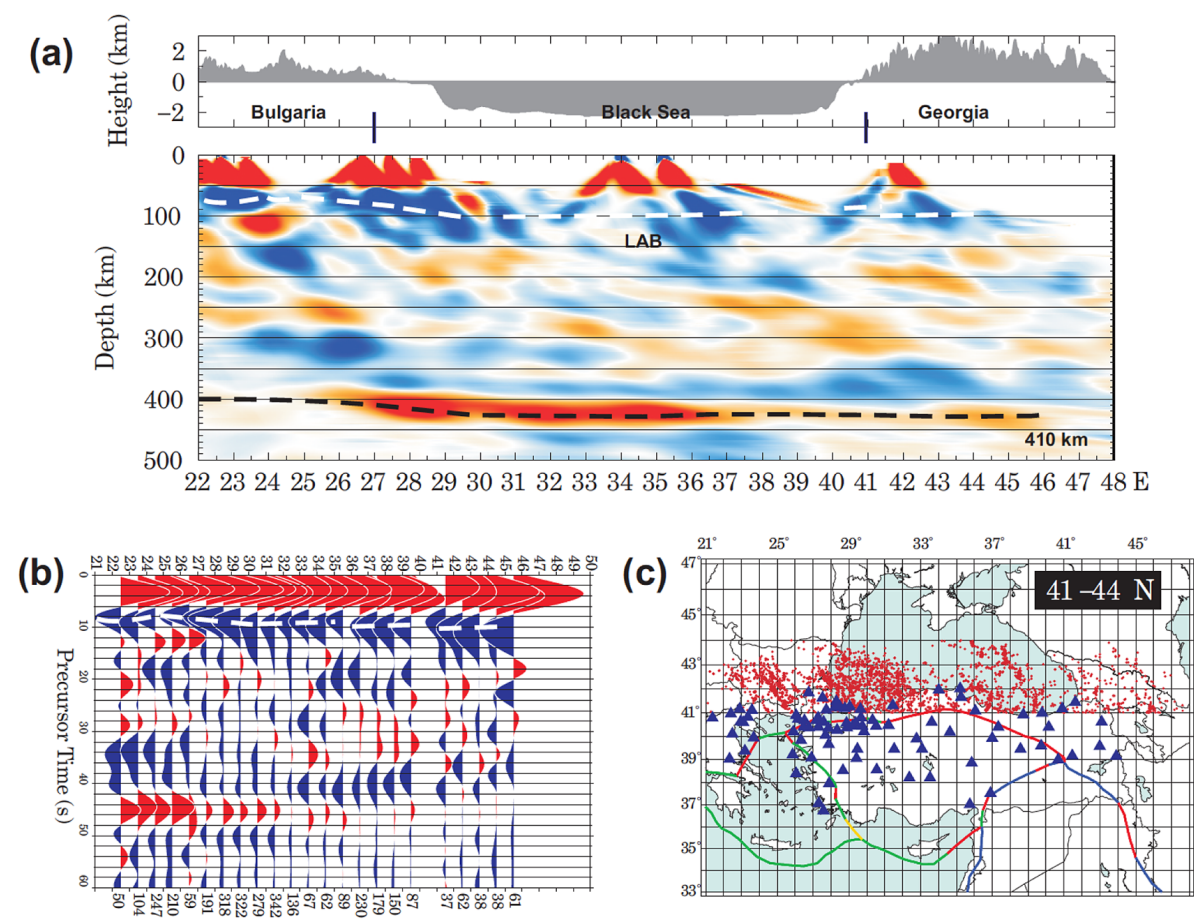

Figure 10. Same as Fig. 5 for an east-west profile between 41 and $44^{\circ} \mathrm{N}$ along northern Anatolia and the southern part of the Black Sea. The LAB appears very similar to the central Anatolian profile (Fig. 9). 

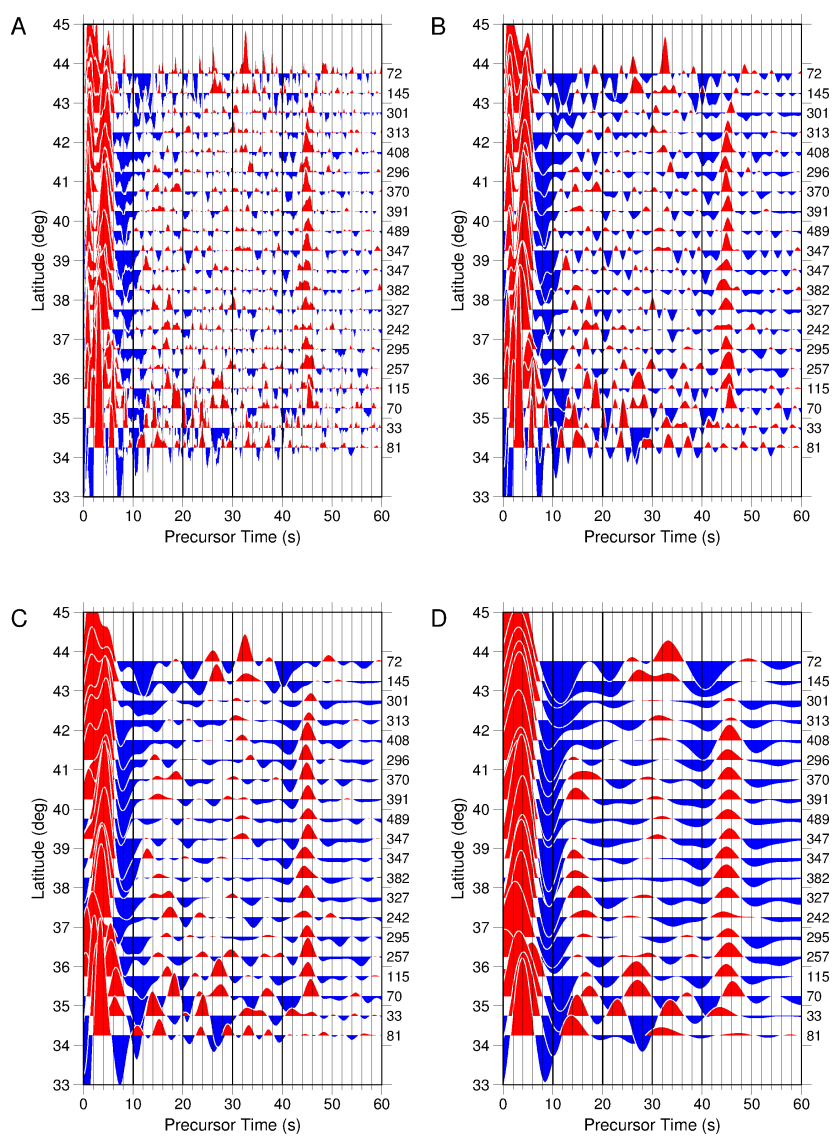

Figure 11. Same S-receiver functions as in Fig. 6b for different filters: (a) no filter, (b) $2 \mathrm{~s}$ low-pass filter, (c) $4 \mathrm{~s}$ low-pass filter and (d) $8 \mathrm{~s}$ low-pass filter. At shorter periods (a and b) the LAB (blue signal around $10 \mathrm{~s}$ ) may consist of several smaller discontinuities. Only for the 6 and $8 \mathrm{~s}$ low-pass filters it appears as a single discontinuity. In contrast, the Moho and the discontinuity at $410 \mathrm{~km}$ depth (red signals around 5 and $45 \mathrm{~s}$, respectively) remain as sharp single discontinuities at all periods, suggesting that this behavior is due to structure rather than to the higher noise levels at shorter periods.

al. (2008) and Gök et al. (2011). Sodoudi et al. (2006) found the northern Aegean LAB near $150 \mathrm{~km}$ depth. Additional indications of a thin lithosphere are strong $\mathrm{Lg}$ and $\mathrm{Sn}$ attenuation observations (Gök et al., 2003), and relatively low Sand Pn-wave velocity anomalies (e.g., Maggi and Priestley, 2005; Gök et al., 2007; Al-Lazki et al., 2004). A joint analysis of surface wave group velocities (Rayleigh and Love waves) and teleseismic receiver functions suggests that the average LAB depth is about $90 \mathrm{~km}$ in the Arabian plate and about $70 \mathrm{~km}$ in the Anatolian block (Gök et al., 2007).

However, our observations of the thin lithosphere provide seismological support for the removal of lithosphere beneath entire Anatolia. Indications of lithospheric removal in the region have been given in earlier regional tomography studies (i.e., Wortel and Spakman, 2000; Piromallo and Morelli, 2003). Şengör et al. (2003) proposed the detachment of the
Arabian plate and subsequent upwelling of asthenospheric mantle to explain the high elevation and the lack of a thick mantle lithosphere beneath the Eastern Anatolian Plateau.

\subsection{Subduction of African lithosphere}

In our stacked S-RFs and corresponding depth-migrated images, the African LAB dips flatly to the north with an angle of $20-30^{\circ}$ and reaches down to almost $150 \mathrm{~km}$ depth beneath Anatolia and the Aegean (Figs. 5 and 6). This is similar to the observed slab geometry found by a recent Rayleigh wave tomography by Bakirci et al. (2012). It is also similar to receiver function results from $\mathrm{Li}$ et al. (2003) and Sodoudi et al. (2006, 2015). In contrast to that, the African slab observed with tomographic methods reaches into the lower mantle with a dip of $40-50^{\circ}$ (e.g., Wortel and Spakman, 2000). What is the reason for the differences in the observations of the two types of data? Comparing our data with the synthetics in Fig. 4, we realize that for a slab dip $>40^{\circ}$ only events with a back azimuth between 160 and $200^{\circ}$ would contribute to the slab images. However, we have only very few events from the south (see Fig. 2). A steep part of the slab is thus not expected to show on our images, and its absence on our image does not rule out the presence of a deeper slab. Figure 4 also shows that slabs with a dip of $20-30^{\circ}$ can be observed relatively well with S-receiver functions. All our images of the subducting African plate are only obtained from the shallow and flat dipping part of the slab. Features of slab break-off were inferred later from teleseismic tomography images (Lei and Zhao, 2007; Zor, 2008). Without requiring slab break-off models, recent geodynamic models (Gögüuss and Pysklywec, 2008; Komut et al., 2012; Göğüus, 2014) associate presentday high topography, lithospheric thinning and hot surface heat flow with vertical flow and very high thermal conditions (e.g., $1300-1400^{\circ} \mathrm{C}$ ) of the uppermost mantle that resulted in the delamination of lithosphere, which was originally proposed by Bird (1979) for the Colorado Plateau.

Biryol et al. (2011) observed a wide gap between the highvelocity anomalies of the subducting Hellenic and Cyprus slabs, which they interpreted as slab tear. Our north-south profile at the transition of the Hellenic and Cyprus slabs (Fig. 6) is too broad to resolve such a slab tear. The dipping features of the African Moho along the Hellenic and Cyprus trenches differ, implying that the subduction is only shallow toward the south of Cyprus (Figs. 5, 6). The absence of trench-perpendicular extension on the over-riding central Anatolia is different from the western Anatolia and the Aegean and was previously considered to be the consequence of a lower subduction angle of the African slab along the Cyprus trench (Barka and Reilinger, 1997). Changing slab geometry with decreasing dip angle from west to east was previously suggested to result from the Eratosthenes Seamount beneath Cyprus resisting subduction (Kempler and Ben-Avraham, 1987; Barka and Reilinger, 1997). The eastwest profile along the southern boundary of Anatolia (Fig. 8) 
provides more detailed information. Here, we see that the African (or Hellenic) slab is apparently dipping to the east towards Cyprus where it reaches about $150 \mathrm{~km}$ depth; this geometry can be interpreted as a northward-directed dip of the African plate, resulting in a structural boundaries that are inclined to the north and east. To the east of Cyprus, we see the flat Arabian LAB near $100 \mathrm{~km}$ depth (Fig. 8), clearly discontinuous with the African slab LAB. This transition occurs significantly west of the Dead Sea Transform fault (which is at $35-36^{\circ}$ E, see Fig. 1), which might indicate that the Dead Sea Transform fault is inclined to the west.

\subsection{Depth of the NAF}

The depth extent of the lithosphere across the NAF is still a controversial issue. Biryol et al. (2011) found a sharp velocity contrast across the NAF reaching down to 100 $150 \mathrm{~km}$ depth. Fichtner et al. (2013b) identified a narrow lowvelocity zone reaching about $100 \mathrm{~km}$ depth and interpreted it as a zone of weakness. However, Salaün et al. (2012) did not find any evidence for a lithosphere penetrating NAF in a surface wave study, inverting fundamental-mode Rayleigh wave phase velocity maps. Similarly, we also do not observe any significant contrast in the delay times of the LAB signals across the NAF (Fig. 6). We conclude therefore that lithospheric depths and average velocities are very similar on both sides of the fault. We also tested narrower northsouth profiles and obtained similar results, although the data quality worsens when fewer traces are summed. The oblique pattern of the fast polarization direction inferred from the SKS measurements relative to the actual orientation of the NAF is an indication that the NAF is a relatively shallow feature not linked to a deep deformation zone (e.g., Paul et al., 2014). These observations are different from those found in northeast Tibet (Leon Soto et al., 2012; Eken et al., 2013) where fast anisotropy directions within the entire lithosphere are nearly parallel to the strike of the North and South Kunlun faults. In contrast to northern Anatolia, significant differences in crustal and lithospheric thickness are observed across the San Andreas Fault in southern California based on P- and S-receiver functions (Lekic et al., 2011; Miller et al., 2014).

\subsection{Mantle transition zone discontinuities}

We observed the 410 discontinuity beneath most of Anatolia. This discontinuity is shallowest beneath western Anatolia at $\sim 390 \mathrm{~km}$ depth and deepens smoothly towards central Anatolia to $420 \mathrm{~km}$. The depth is approximately constant below central Anatolia and deepens again across eastern Anatolia from 410 to $430 \mathrm{~km}$ (Fig. 9). The reason for the lateral variation of the 410 depth in Fig. 9 are probably the lateral velocity variations in the sub-lithospheric mantle, because the LAB itself is flat. Large temperature variations across Anatolia in the transition zone, which would cause an actual de- flection of the 410 depth, seem less likely. We leave studies of the upper-mantle discontinuities to a future analysis using Preceiver functions that are more suitable for this purpose. In the context of this study, these observations are mainly used to verify the reliability of our data. Another observation is a negative but more scattered discontinuity about $50 \mathrm{~km}$ above the 410 in the entire area. Such a discontinuity is known globally (Tauzin et al., 2010) and considered to be caused by a low-velocity layer containing liquids or partial melts. We do not observe any other prominent discontinuity between the $\mathrm{LAB}$ and the low-velocity zone on top of the 410 on larger scale, especially no clear indications for the Lehmann discontinuity, which has been observed below the north-western United States (Kind et al., 2015) and large parts of Scandinavia (Kind et al., 2013) using S-receiver functions.

\section{Conclusions}

The depth of the LAB beneath the entire region of Anatolia varies between 80 and $100 \mathrm{~km}$, and in particular does not change when crossing the North Anatolian and East Anatolian fault zones. This indicates that the thickness of the lithosphere is similar beneath Anatolia and the neighboring edges of the Eurasian and Arabian plates. An exception is the lithospheric thickness near $150 \mathrm{~km}$ in the northern Aegean (Sodoudi et al., 2006). In southern Anatolia, the subducting African lithosphere (LAB) between the Aegean and western Cyprus is imaged down to a depth of about $150 \mathrm{~km}$, dipping to the north and east. Synthetic seismogram calculations have shown that a steeper-dipping deeper slab would not have been imaged by S-receiver functions, however. To the east of Cyprus a shallow LAB is observed (similar to the Arabian LAB) with apparently no indication of African subduction.

Acknowledgements. This research was supported by the Deutsche Forschungsgemeinschaft. We thank the Kandilli Observatory and Earthquake Research Institute, National Earthquake Monitoring Center (KOERI-NEMC), Turkey; Aristotle University Thessaloniki (HT-Net), Greece; National Observatory of Athens (NOA), Greece; and the GEOFON Data Center at the GFZ Potsdam, Germany, for their efforts in maintaining free public access of digital recordings to the scientific community. T. Eken was funded by a Humboldt Research Fellowship for Postdoctoral Researchers provided by the Alexander von Humboldt Foundation. T. Taymaz thanks National Scientific and Technological Research Council of Turkey (TÜBİTAK), Turkish Academy of Sciences (TÜBA) in the framework for Young Scientist Award Program (TT-TÜBA-GEBIP 20012-17), and the Alexander von Humboldt Foundation Research Fellowship Award for financial support. We thank Jim Mechie and Eric Sandvol for reading the manuscript and for helpful comments. We also thank Andrew Frederiksen for providing the RAYSUM code used in the synthetic RF calculations. Finally we like to thank Wolfram Geissler and another anonymous reviewer for their very helpful comments. 
The article processing charges for this open-access publication were covered by a Research

Centre of the Helmholtz Association.

Edited by: J. Plomerova

\section{References}

Al-Lazki, A. I., Seber, D., Sandvol, E., Turkelli, N., Mohamad, R., and Barazangi, M.: Tomographic Pn velocity and anisotropy structure beneath the Anatolian Plateau (eastern Turkey) and the surrounding regions, Geophys. Res. Lett., 30, 8043, doi:10.1029/2003GL017391, 2004.

Angus, D., Wilson, D., Sandvol, E., and Ni, J.: Lithospheric structure of the Arabian and Eurasian collision zone in eastern Turkey from S-wave receiver functions, Geophys. J. Int., 166, 13351346, doi:10.1111/j.1365-246X.2006.03070.x, 2006.

Armijo, R., Meyer, B., Hubert, A., and Barka, A.: Westward propagation of the North Anatolian fault into the northern Aegean: timing and kinematics, Geology, 27, 267-270, 1999.

Bakirci, T., Yoshizawa, K., and Özer, M. F.: Three-dimensional S wave structure of the upper mantle beneath Turkey from surface wave tomography, Geophys. J. Int., 190, 1058-1076, 2012.

Barka, A. and Reilinger, R.: Active tectonics of the eastern Mediterranean region: deduced from GPS, neotectonic and seismicity data, Ann. Geofis., XL 3, 587-610, 1997.

Bécel, A., Laigle, M., de Voogd, B., Hirn, A., Taymaz, T., Galvé, A., Shimamura, H., Murai, Y., Lépine, J.-C., Sapin, M., and Özalaybey, S.: Moho, crustal architecture and deep deformation under the North Marmara Trough, from the SEISMARMARA Leg1 offshore-onshore reflection-refraction survey, Tectonophysics, 467, 1-21, doi:10.1016/j.tecto.2008.10.022, 2009.

Bécel, A., Laigle, M., de Voogd, B., Hirn, A., Taymaz, T., YolsalÇevikbilen, S., and Shimamura, H.: North Marmara Trough architecture of basin infill, basement and faults, from PSDM reflection and OBS refraction seismics, Tectonophysics, 490, 1-14, doi:10.1016/j.tecto.2010.04.004, 2010.

Bird, P.: Continental delamination and the Colorado Plateau, J. Geophys. Res., 84, 7561-7571, doi:10.1029/JB084iB13p07561, 1979.

Bird, P.: An updated digital model of plate boundaries, Geochem. Geophy. Geosy., 4, 1027, doi:10.1029/2001GC000252, 2003.

Biryol, C. B., Beck, S. L., Zandt, G., and Özacar, A. A.: Segmented African lithosphere beneath the Anatolian region inferred from teleseismic P-wave tomography, Geophys. J. Int., 184, 10371057, 2011.

Bulut, F., Bohnhoff, M., Eken, T., Janssen, C., Kilic, T., and Dresen, G.: The East Anatolian Fault Zone: seismotectonic setting and spatiotemporal characteristics of seismicity based on precise earthquake locations, J. Geophys. Res.-Solid, 117, B07304, doi:10.1029/2011JB008966, 2012.

Dewey, J. F. and Şengör, A. M. C.: Aegean and surrounding regions: complex multiplate and continuum tectonics in a convergent zone, Geol. Soc. Am. Bull., 90, 84-92, doi:10.1130/00167606(1979)90<84:AASRCM>2.0.CO;2, 1979.

Eken, T., Tilmann, F., Mechie, J., Zhao, W. J., Kind, R., Su, H. P., Xue, G. Q., and Karplus, M.: Seismic anisotropy from SKS splitting beneath northeastern Tibet, B. Seismol. Soc. Am., 103, 3362-3371, doi:10.1785/0120130054, 2013.

Faccenna, C., Jolivet, L., Piromallo, C., and Morelli, A.: Subduction and the depth of convection in the Mediterranean mantle, J. Geophys. Res., 108, 2099, doi:10.1029/2001JB001690, 2003.

Faccenna, C., Bellier, O., Martinod, J., Piromallo, C., and Regard, V.: Slab detachment beneath eastern Anatolia: a possible cause for the formation of the North Anatolian Fault, Earth Planet. Sc. Lett., 242, 85-97, doi:10.1016/j.epsl.2005.11.046, 2006.

Faccenna, C., Becker, T. W., Auer, L., Billi, A., Boschi, L., Brun, J. P., Capitanio, F. A., Funiciello, F., Horvath, F., Jolivet, L., Piromallo, C., Royden, L., Rossetti, F., and Serpelloni, E.: Mantle dynamics in the Mediterranean, Rev. Geophys., 52, 283-332, doi:10.1002/2013RG000444, 2014.

Fichtner, A., Saygin, E., Taymaz, T., Cupillard, P., Capdeville, Y., and Trampert, J.: The deep structure of the North Anatolian Fault Zone, Earth Planet. Sc. Lett., 373, 109-117, 2013a.

Fichtner, A., Trampert, J., Cupillard, P., Saygin, E., Taymaz, T., Capdeville, Y., and Villasenor, A.: Multiscale full waveform inversion, Geophys. J. Int., 194, 534-556, doi:10.1093/gji/ggt118, 2013b.

Fischer, K. M., Ford, H. A., Abt, D. L., and Rychert, C. A.: The lithosphere asthenosphere boundary, Annu. Rev. Earth Pl. Sc., 38, 551-575 doi:10.1146/annurev-earth-040809-152438, 2010.

Frederiksen, A. W. and Bostock, M. G.: Modelling teleseismic waves in dipping anisotropic structures, Geophys. J. Int., 141, 401-412, 2000.

Gans, C. R., Beck, S. L., Zandt, G., Biryol, C. B., and Özacar, A. A.: Detecting the limit of slab break-off in central Turkey: new highresolution Pn tomography results, Geophys. J. Int., 179, 1566$1572,2009$.

GEOFON Data Centre: GEOFON Seismic Network, Deutsches GeoForschungsZentrum GFZ, doi:10.14470/TR560404, 1993.

Göğüş, O. H. and Pysklywec, R. N.: Mantle lithosphere delamination driving plateau uplift and synconvergent extension in eastern Anatolia, Geology, 36, 723-726, doi:10.1130/G24982A.1, 2008.

Göğüş, O. H.: Rifting and subsidence following lithospheric removal in continental back arcs, Geology, 43, 3-6, doi:10.1130/G36305.1, 2014.

Gök, R., Sandvol, E., Törkelli, N., Seber, D., and Barazangi, M.: $\mathrm{Sn}$ attenuation in the Anatolian and Iranian plateau and surrounding regions, Geophys. Res. Lett., 30, 8042, doi:10.1029/2003GL018020, 2003.

Gök, R., Pasyanos, M., and Zor, E.: Lithospheric structure of the continent-continent collision zone: eastern Turkey, Geophys. J. Int., 169, 1079-1088, doi:10.1111/j.1365-246X.2006.03288.x, 2007.

Gök, R., Mellors, R. J., Sandvol, E., Pasyanos, M., Hauk, M., Takedatsu, R., Yetirmishli, G., Teoman, U., Turkelli, N., Godoladze, T., and Javakishvirli, Z.: Lithospheric velocity structure of the Anatolian Plateau-Caucasus-Caspian region, J. Geophys. Res., 116, B05303, doi:10.1029/2009JB000837, 2011.

Hanka, W. and Kind, R.: The GEOFON Program, Ann. Geophys., XXXVII, 1060-1065, 1994.

Hopper, E., Ford, H. E., Fischer, K. M., and Lekic, V.: The lithosphere-asthenosphere boundary and the tectonic-magmatic history of the northwestern United States, Earth Planet Sc. Lett., 402, 69-81, doi:10.1016/j.eps1.2013.12.016, 2013. 
Jackson, J., Haines, A. J., and Holt, W. E.: The horizontal velocity field in the deforming Aegean region determined from seismic moment tensors of earthquakes, J. Geophys. Res., 97, 1765717684, doi:10.1029/92JB01585, 1992.

Jones, A. G., Plomerova, J., Korja, T., Sodoudi, F., and Spakman, W.: Europe from the bottom up: a statistical examination of the central and northern European lithosphere-asthenosphere boundary from comparing seismological and electromagnetic observations, Lithos, 120, 14-29, 2010.

Kalafat, D., Kekovali, K., and Pinar, A.: A Cataloque of Sources Parameters of Moderate and Strong Earthquakes for Turkey and Surrounding Area, EGU General Assembly 2008, Vienna, Austria, 13-18 April 2008, Geophysical Research Abstracts, Vol. 10, EGU2008-A-07256, 2008.

Karabulut, H., Paul, A., Ergun, T. A., Hatzfeld, D., Childs, D. M., and Aktar, M.: Long-wavelength undulations of the seismic Moho beneath the strongly stretched western Anatolia, Geophys. J. Int., 194, 450-464, 2013.

Kempler, D. and Ben-Avraham, Z.: The tectonic evolution of the Cyprean arc, Annales Tectonicae, 1, 58-71, 1987.

Keskin, M.: Magma generation by slab steepening and breakoff beneath a subduction-accretion complex: an alternative model for collision-related volcanism in eastern Anatolia, Turkey, Geophys. Res. Lett., 30, 8046, doi:10.1029/2003GL018019, 2003.

Kind, R.: Long range propagation of seismic energy in the lower lithosphere, J. Geophys., 40, 189-202, 1974.

Kind, R., Yuan, X., and Kumar, P.: Seismic receiver functions and the lithosphere-asthenosphere boundary, Tectonophysics, 536537, 25-43, 2012.

Kind, R., Sodoudi, F., Yuan, X., Shomali, H., Roberts, R., Gee, D., Eken, T., Bianchi, M., Tilmann, F., Balling, N., Jacobsen, B. H., Kumar, P., and Geissler, H. W.: Scandinavia: a former Tibet?, Geochem. Geophy. Geosy., 14, 4479-4487, doi:10.1002/ggge.20251, 2013.

Kind, R., Yuan, X., Mechie, J., and Sodoudi, F.: Structure of the upper mantle in the north-western and central United States from USArray S-receiver functions, Solid Earth Discuss., 7, 10251057, doi:10.5194/sed-7-1025-2015, 2015.

Komut, T., Gray, R., Göğüş, H. O., and Pysklywec, R. N.: Mantle flow uplift of western Anatolia and the Aegean: interpretations from Geophysical Analyses and Geodynamic Modelling, J. Geophys. Res., 117, B11412, doi:10.1029/2012JB009306, 2012.

Kumar, P., Yuan, X., Kind, R., and Mechie, J.: The lithosphereasthenosphere boundary observed with USArray receiver functions, Solid Earth, 3, 149-159, doi:10.5194/se-3-149-2012, 2012a.

Kumar, P., Kind, R., Yuan, X., and Mechie, J.: USArray receiver function images of the LAB, Seismol. Res. Lett., 83, 486-491, doi:10.1785/gssrl.83.3.486, 2012b.

Laigle, M., Becel, A., de Voogd, B., Hirn, A., Taymaz, T., and Ozalaybey, S.: A first deep seismic survey in the Sea of Marmara: deep basins and whole crust architecture and evolution, Earth Planet Sc. Lett., 270, 168-179, 2008.

Lei, J. and Zhao, D.: Teleseismic evidence for a break-off subducting slab under eastern Turkey, Earth Planet. Sc. Lett., 257, 14-28, 2007.

Lekic, V., French, S. W., and Fischer, K. M.: Lithospheric thinning beneath rifted regions of southern California, Science, 334, 783787, doi:10.1126/science.1208898, 2011.
Leon Soto, G., Sandvol, E., Ni, J. F., Flesch, L. M., Hearn, T. M., Tilmann, F., Chen, Y. J., and Brown, L.: Significant and vertically coherent seismic anisotropy beneath eastern Tibet, J. Geophys. Res., 117, B05308, doi:10.1029/2011JB008919, 2012.

Levander, A. and Miller, M. S.: Evolutionary aspects of lithosphere discontinuity structure in the western U.S., Geochem. Geophy. Geosy., 13, Q0AK07, doi:10.1029/2012GC004056, 2012.

Li, X., Bock, G., Vafidis, A., Kind, R., Harjes, H.-P., Hanka, W., Wylegalla, K., van der Meijde, M., and Yuan, X.: Receiver function study of the Hellenic subduction zone: imaging crustal thickness variations and the oceanic Moho of the descending African lithosphere, Geophys. J. Int., 155, 733-748, 2003.

Maggi, A. and Priestley, K.: Surface waveform tomography of the Turkish-Iranian Plateau, Geophys. J. Int., 160, 1068-1080, 2005.

McKenzie, D.: Active tectonics of the Alpine-Himalayan belt: the Aegean Sea and surrounding regions, Geophys. J. Roy. Astr. S., 55, 217-254, 1978.

Miller, S. M., Zhang, P., and Dolan, J. F.: Moho structure across the San Jacinto Fault zone: insights into strain localization at depth, Lithosphere, 6, 43-47, doi:10.1130/1295.1, 2014.

Okay, A. I. and Satır, M.: Coeval plutonism and metamorphism in a latest Oligocene metamorphic core complex in northwest Turkey, Geol. Mag., 137, 495-516, 2000.

Özacar, A. A., Gilbert, H., and Zandt, G.: Upper mantle discontinuity structure beneath East Anatolian Plateau (Turkey) from receiver functions, Earth Planet. Sc. Lett., 269, 427-435, doi:10.1016/j.eps1.2008.02.036, 2008.

Paul, A., Karabulut, H., Mutlu, A. K., and Salaun, G.: A comprehensive and densely sampled map of shear-wave azimuthal anisotropy in the Aegean-Anatolia region, Earth Planet. Sc. Lett., 389, 14-22, doi:10.1016/j.eps1.2013.12.019, 2014.

Piromallo, C. and Morelli, A.: P-wave tomography of the mantle under the Alpine-Mediterranean area, J. Geophys. Res., 108, 2065, doi:10.1029/2002JB001757, 2003.

Reilinger, R., McClusky, S., Vernant, P., Lawrence, S., Erginta, S., Cakmak, R., Ozener, H., Kadirov, F., Guliev, I., Stepanyan, R., Nadariya, M., Hahubia, G., Mahmoud, S., Sakr, K., ArRajehi A., Paradissis, D., Al-Aydrus, A., Prilepin, M., Guseva, T., Evren, E., Dmitrotsa, A., Filikov, S.V., Gomez, F. Al-Ghazzi, R. and Karam, G.: GPS constraints on continental deformation in the Africa-Arabia-Eurasia continental collision zone and implications for the dynamics of plate interactions, J. Geophys. Res., 111, B05411, doi:10.1029/2005JB004051, 2006.

Rychert, C. A. and Shearer, P. M.: A global view of the lithosphere-asthenosphere boundary, Science, 324, 495-498, doi:10.1126/science.1169754, 2009.

Rychert, C. A., Shearer, P. M., and Fischer, K. M.: Scattered wave imaging of the lithosphere-asthenosphere boundary, Lithos, 120, 173-185, 2010.

Salaün, G., Pedersen, H. A., Paul, A., Farra, V., Karabulut, H., Hatzfeld, D., Papazachos, C., Childs, D. M., Pequegnat, C., and SIMBAAD Team: High-resolution surface wave tomography beneath the Aegean-Anatolia region: constraints on upper-mantle structure, Geophys. J. Int., 190, 406-420, doi:10.1111/j.1365246X.2012.05483.x, 2012.

Sato, T., Kasahara, J., Taymaz, T., Ito, M., Kamimura, A., Hayakawa, T. and Tan, O.: A study of microearthquake seismicity and focal mechanisms within the Sea of Marmara (NW Turkey) using ocean-bottom seismometers 
(OBS), Special Issue of Tectonophysics, 391, 303-314, doi:10.1016/j.tecto.2004.07.018, 2004.

Saunders, P., Priestley, K., and Taymaz, T.: Variations in the crustal structure beneath western Turkey, Geophys. J. Int., 134, 373389, 1998.

Schildgen, T. F., Yildirim, C., Cosentino, D., and Strecker, M. R.: Linking slab break-off, Hellenic trench retreat, and uplift of the central and eastern Anatolian plateaus, Earth-Sci. Rev., 128, 147-168, doi:10.1016/j.earscirev.2013.11.006, 2014.

Schneider, F. M., Yuan, X., Schurr, B., Mechie, J.,Sippl, C., Haberland, C., Minaev, V., Oimahmadov, I., Gadoev, M., Radjabov, N., Abdybachaev, U., Orunbaev, S., and Negmatullaev, S.: Seismic imaging of subducting continental lower crust beneath the Pamir, Earth Planet. Si. Lett., 375, 101-112, 2013.

Şengör, A. M. C. and Kidd, W. S. F.: The post-collisional tectonics of the Turkish-Iranian Plateau and a comparison with Tibet, Tectonophysics, 55, 361-376, 1979.

Şengör, A. M. C., Özeren, S., Genç, T., and Zor, E.: East Anatolian high plateau as a mantle supported, north-south shortened domal structure, Geophys. Res. Lett., 30, 8045, doi:10.1029/2003GL017858, 2003.

Sodoudi, F., Kind, R., Hatzfeld, D., Priestley, K., Hanka, W., Wylegalla, K., Stavrakakis, G., Vafidis, A., Harjes, H. P., and Bohnhoff, M.: Lithospheric structure of the Aegean obtained from $\mathrm{P}$ and $\mathrm{S}$ receiver functions, J. Geophys. Res., 111, B12307, doi:10.1029/2005JB003932, 2006.

Sodoudi, F., Yuan, X., Kind, R., Lebedev, S., Adam, J. M.-C., Kästle E., and Tilmann, F.: Seismic evidence for stratification in composition and anisotropic fabric within the thick lithosphere of Kalahari Craton, Geochem. Geophy. Geosy., 14, 5393-5412, doi:10.1002/2013GC004955, 2013.

Sodoudi, F., Brüstle, A., Meier, T., Kind, R., Friederich, W., and EGELADOS working group: Receiver function images of the Hellenic subduction zone and comparison to microseismicity, Solid Earth, 6, 135-151, doi:10.5194/se-6-135-2015, 2015.

Tauzin, B., Debayle, E., and Wittlinger, G.: Seismic evidence for global low-velocity layer within the Earth's upper mantle, Nat. Geosci., 3, 718-721, doi:10.1038/NGEO969, 2010.
Taymaz, T., Jackson, J. A., and Westaway, R.: Earthquake mechanisms in the Hellenic Trench near Crete, Geophys. J. Int., 102, 695-731, 1990.

Taymaz, T., Jackson, J. A., and McKenzie, D.: Active tectonics of the north and central Aegean Sea, Geophys. J. Int., 106, 433-490, 1991a.

Taymaz, T., Eyidogan, H., and Jackson, J. A.: Source parameters of large earthquakes in the East Anatolian Fault zone (Turkey), Geophys. J. Int., 106, 537-550, 1991 b.

Taymaz, T., Westaway, R., and Reilinger, R. (Guest Eds.): Active faulting and crustal deformation in the eastern Mediterranean region, Special Issue of Tectonophysics, 391, 1-4, 1-9, doi:10.1016/j.tecto.2004.07.005, 2004.

Vanacore, E. A., Taymaz, T., and Saygin, E.: Moho structure of the Anatolian Plate from receiver function analysis, Geophys. J. Int., 193, 329-337, 2013.

Vinnik, L. P., Erduran, M., Oreshin, S. I., Kosarev, G. L., Kutlu, Y. A., Çakir, Ö., and Kiselev, S. G.: Joint inversion of P- and S-receiver functions and dispersion curves of Rayleigh waves: the results for the Central Anatolian Plateau, Izv.-Phys. Solid Earth, 50, 622-631, 2014.

Wortel, M. J. R. and Spakman, W.: Subduction and slab detachment in the Mediterranean-Carpathian region, Science, 290, 1910 1917, doi:10.1126/science.290.5498.1910, 2000.

Yuan, X., Kind, R., Li, X., and Wang, R.: The S receiver functions; synthetics and data example, Geophys. J. Int., 165, 555564, doi:10.1111/j.1365-246X.2006.02885.x, 2006.

Zor, E.: Tomographic evidence of slab detachment beneath eastern Turkey and the Caucasus, Geophys. J. Int., 175, 1273-1282, 2008.

Zor, E., Sandvol, E., Gurbuz, C., Turkelli, N., Seber, D., and Barazangi, M.: The crustal structure of the East Anatolian Plateau (Turkey) from receiver functions, Geophys. Res. Lett., 30, 8044, doi:10.1029/2003GL018192, 2003.

Zor, E., Özalaybey, S., and Gürbüz, C.: The crustal structure of the eastern Marmara region, Turkey by teleseismic receiver functions, Geophys. J. Int., 167, 213-222, doi:10.1111/j.1365246X.2006.03042.x, 2006. 